\title{
Investigation of the quality of seeds of Anethum graveolens varieties Gribovsky and Lesnogorodsky by method of thermal analysis
}

\author{
(C) Elena V. Zueva, ${ }^{1}{ }^{+}$Sergey L. Belopukhov, ${ }^{2}$ and Ravil F. Baybekov ${ }^{3}$ \\ ${ }^{1,2}$ Department of Chemistry; ${ }^{3}$ Department of Soil Science, Geology and Landscape Science. Russian State \\ Agrarian University - Moscow Agricultural Academy Named after K.A. Timiryazev. Timiryazevskaya St., 49. \\ Moscow, 127434. Russia. Phone: +7 (499) 976-16-28. E-mail: SBelopuhov@rgau-msha.ru
}

Keywords: dill, Anethum graveolens L, chemical composition, differential thermal analysis, nicosulfuron, activation energy.

\section{Abstract}

The paper presents data on the study of the chemical composition of dill (Anethum graveolens L) using foliar treatment of vegetative plants with the growth-regulating agent Nicosulfuron [2-(4,6-dimethoxypyrimidin-2ylcarbomoyl-sulfamoyl) $-N, N$-dimethylnicotinamide]. Field experiments were carried out at the agrobiological station of the Humanitarian and Technological University of the city of Orekhovo-Zuevo, Moscow Region in 2016-2018. The soil of the experimental plots is sod-podzolic medium loamy. Plants were treated with a solution of Nicosulfuron with a concentration of $0.1 \mathrm{~g} / 1$ according to the active substance. It was found that foliar treatment of vegetative plants with a solution of 2-(4,6-dimethoxypyrimidin-2-ylcarbomoyl-sulfamoyl)- $N, N$-dimethylnicotinamide led to a change in the concentrations of macrocomponents in the seeds of dill varieties Gribovsky and Lesnogorodsky. Differential thermal analysis of DTA) of dill seeds was carried out using a thermoanalytical complex based on a derivatograph. The sample heating rate in a platinum crucible was 5,10 , and 20 degrees per minute. The DTA method showed a significant difference in the component composition of the organic matter of seeds of both varieties. 6 organic components can be grouped into two groups - with thermal decomposition temperatures of $200-400{ }^{\circ} \mathrm{C}$ and $400-600{ }^{\circ} \mathrm{C}$. The treatment with Nicosulfuron leads to a shift in the accumulation of synthesized spare components of seeds towards easily degradable (up to $400{ }^{\circ} \mathrm{C}$ ) components. This treatment effect is manifested in the fact that in the total mass of organic components of dill seeds (at the level of $87 \%$ ), the fraction of readily decomposable organic matter is $64-70 \%$ for both varieties. In the control variant, without treatment with the drug, the biosynthesis of hardly degradable components, probably having a high molecular weight, and for high-molecular compounds having a high degree of polymerization, occurs. At the same time, the total activation energy for organic compounds in the control is $30-40 \%$ higher compared to the samples that were treated with Nicosulfuron.

\section{References}

[1] L.I. Shashilova. World diversity of dill and its breeding value. Leningrad: Agropromizdat. 1999. 127p. (russian)

[2] M.M. Tsiunel. Morphological features of the leaf blade and the variety of dill morphotypes. Vegetables of Russia. 2019. No.6(50). P.31-35. (russian)

[3] A. Yili, H.A. Aisa, V.V. Maksimov, O.N. Veshkurova, S.I. Salikhov. Chemical composition and antimicrobial activity of essential oil from seeds of Anethum graveolens growing in Uzbekistan. Chemistry of Natural Compounds. 2009. Vol.45. No.2. P.280-281

[4] A.V. Borisova, N.V. Makarova. Antioxidant activity in vitro of spices used in human nutrition. Nutrition issues. 2016. P.120-125. (russian)

[5] Y. Chen, H. Zeng, J. Tian, X. Ban, B. Ma, Y. Wang. Antifungal mechanism of essential oil from Anethum graveolens seeds against Candida albicans. Journal of Medical Microbiology. 2013. Vol.62. No.8. P.11751183.

[6] Ye.V. Zuyeva, S.L. Belopukhov. Comparative analysis of biologized and intensive agricultural technologies on the example of dill (Anethum graveolens). Bulletin of the Chuvash State Agricultural Academy. 2019. No2(9). P.16-20. (russian)

[7] I.N. Semenova, G.SH. Singizova, A.B. Zulkaranayev, G.SH. Il'bulova. The influence of copper and lead on the growth and development of plants on the example of Anethum graveolens L. Modern problems of science and education. 2015. No.3. P.588. (russian) 
[8] O.G. Kulikova, D.I. Mal'tsev, A.P. Il'ina, A.V. Burdina, V.P. Yamskova, I.A. Yamskov. Biologically active peptides isolated from odorous dill Anethum graveolens L. Applied Biochemistry and Microbiology. 2015. Vol.51. No.3. P.348. (russian)

[9] H. Hosseinzadeh, G.R. Karimi, M. Ameri. Effects of Anethum graveolens L. seed extracts on experimental gastric irritation models in mice. BMC Pharmacol. 2002. No.2. P.21.

[10] N. Takahashi, L. Yao, M. Kim, H. Sasako, M. Aoyagi, J. Shono, N. Tsuge, T. Goto, T. Kawada. Dill seed extract improves abnormalities in lipid metabolism through peroxisome proliferator-activated receptor- $\alpha$ (PPAR $\alpha$ ) activation in diabetic obese mice. Mol. Nutr. Food Res. 2013. Vol.57. No.7. P.1295-1299.

[11] M.D. Dimov, K.Z. Dobreva, A.S. Stoyanova. Chemical composition of the dill essential oils (Anethum graveolens L.) from Bulgaria. Bulgarian Chemical Communications. 2019. Vol.51. No.1. P.214-216.

[12] M. Madandoust, M. Fooladchang. Effect of nitrogen fertilizer on essential oil content and its compositions in Anethum graveolens L. Journal of Essential Oil-Bearing Plants. 2018. Vol.21. No.5. P.1266-1271.

[13] E.V. Zuyeva, R.F. Baybekov, S.L. Belopukhov, KH.V. Sharafutdinov. The effect of nicosulfuron on the change in the ratio of vitamins in dill (Anethum graveolens L.). Agriculture. 2020. No.5. P.34-37. (russian)

[14] S.L. Belopukhov, E.A. Grishina, I.I. Dmitrevskaya, V.M. Lukomets, I.V. Uschapovsky. Effect of humicfulvic complex on flax fiber and seed yield characteristics. News of the TSHA. 2015. No.4. P.71-81. (russian)

[15] S.L. Belopukhov, I.I. Dmitrevskaya, O.V. Yeliseyeva, A.V. Zhevnerov. Instrumental methods of research of agrosphere objects: textbook. Moscow: Prospect. 2019. 160p. (russian)

[16] U. Uendlandt. Thermal methods of analysis. Trans. from English. edited by V.A. Stepanova, V.A. Bershteyna. Moscow: Mir Publishing House. 1998. 526p. (russian)

[17] S.L. Belopukhov, R.F. Baybekov, V.A. Serkov, O.A. Zharkikh, I.I. Dmitrevskaya. Application of the method of thermal analysis to assess the quality indicators of hemp fiber when using protective and stimulating complexes in agricultural technologies. AgroEcoInfo. 2019. No.4(38). P.38. (russian)

[18] S.L. Belopukhov, I.G. Rekus, L.YU. Komarova, D.G. Demidov, A.L. Kaufman. Application of thermal analysis for expert evaluation of different types of paper. Proceedings of the Tula State University. Technical sciences. 2019. No.12. P.263-268.

[19] A.A. Akhmetova, S.L. Belopukhov. Application of the method of thermal analysis for the study of chicken eggs. Butlerov Communications. 2014. T.39. №10. C.83-88. ROI-jbc-01/14-39-10-83 (russian) 